DOI https://doi.org/10.18551/rjoas.2017-11.65

\title{
THE FLUSHING FOR LEAD IN FRESHWATER SNAIL FILOPALUDINA JAVANICA (VON DEM BUSCH, 1844)
}

\author{
Aminin*, Arfiati Diana, Andayani Sri \\ Aquaculture Program, Faculty of Marine and Fisheries, University of Brawijaya, Indonesia \\ *Email: minin.a1453@gmail.com
}

\begin{abstract}
Increasing industrial activities in Lamongan District is assumed to be followed by the increase on the amount of liters in rivers and ponds. Freshwater snails (Filopaludina javanika v.d Busch 1844) that live in rivers and ponds are always exposed to heavy metals. Based on the result of the measurement of $\mathrm{Pb}$ in freshwater snails in Waung river, Glagah subdistrict, Lamongan, the highest amount of $\mathrm{Pb}$ reached $4.48 \mathrm{mg} / \mathrm{kg}$. This aim of this research was to decrease the amount of $\mathrm{Pb}$ in freshwater snails. This research employed an experimental method using complete randomized design with 4 treatments and 3 repetitions; P1 (6-hour flushing procedure), P2 (12-hour flushing procedure), P3 (18-hour flushing procedure), and P4 (24-hour flushing procedure) with the reduction on the level of $\mathrm{Pb}$ in the "whole organ" of the freshwater snails. The results show that 24-hour of flushing has reduced the amount of $\mathrm{Pb}$ as much as $53.2 \%$, from $2.65 \mathrm{ppm}$, leaving only $1.24 \mathrm{ppm}$. Meanwhile, the least reduction was found in the 6 -hour flushing procedure at $7.2 \%$. The results of the treatments have obtained amount of $\mathrm{Pb}$ under the minimum safety requirement set by BPOM (2009), Fisheries (DKP) No: Kep 17/Men/2004, SK Ditjen POM No. 03725/B/SK/VII/1989, in which it is stated that materials that contain heavy metals less than $1.5 \mathrm{ppm}$ are safe to consume for duck weft and for human. Further researchers are suggested to investigate the accumulation of lead $(\mathrm{Pb})$ in ducks that consume freshwater snails within certain period of time.
\end{abstract}

\section{KEY WORDS}

Flushing, freshwater snails, $\mathrm{Pb}$, well water.

According to the data issued by (Badan Pusat Statistik Kabupaten Lamongan, 2007), Glagah subdistrict lies in a lowland of around $0-25 \mathrm{~m}$ in the central-north of Lamongan district which is famous for its Bonorowo lowland in Sekaran, Maduran, Laren, Karanggeneng, Kalitengah, Turi and Karang Binangun districts. In those areas, freshwater snails (Filopaludina javanika v.d Busch 1844) are easy to find in rivers and ponds at a huge amount of around 100 snails/ $\mathrm{m}^{2}$ year-round. Freshwater snails can be used as ingredients for duck welt. Besides, freshwater snais are also edible for human. People in the area collect freshwater snails from the habitat manually to be sold to duck farmers (Yuliana Firdaus, 22 August 2017). Usually, people collect bigger snails (Filopaludina javanika v.d Busch 1844) of around $25-27 \mathrm{~mm}$ along with their shells for duck welt.

However, the result of a research conducted by Purbalisa and Mulyadi (2013), rice field areas in Glagah subdistrict contained the highest $\mathrm{Pb}$ of $0.67 \mathrm{mg} / \mathrm{kg}$ compared to other subdistricts; Laren $(0.56 \mathrm{mg} / \mathrm{kg})$, Karanggeneng $(0.44 \mathrm{mg} / \mathrm{kg})$ and Kedungpring $(0.22 \mathrm{mg} / \mathrm{kg})$. Whereas, the amount of $\mathrm{Pb}$ found in the bodies of freshwater snails in Glagah subdistrict was also the highest one at $4.47 \mathrm{mg} / \mathrm{kg}$. From the obtained data, it can be implied that there is a certain correlation between freshwater snails which were exposed with $\mathrm{Pb}$ content in their habitat which had accumulated the amount of $\mathrm{Pb}$ in their bodies. Hutagalung (1991) mentioned that the amount of $\mathrm{Pb}$ found in certain organism is usually higher than the amount of $\mathrm{Pb}$ in its habitat due to massive accumulation. The amount of $\mathrm{Pb}$ in freshwater snails might contaminate the ducks that were fed with welt made from the snails.

Siregar (2013) in his research on freshwater snails of Viviparidae family found a high amount of lead in their flesh around $14.6554 \mathrm{mg} / \mathrm{kg}$, making them dangerous to consume. Hence, it prove that organisms living in a certain habitat can be used as an indicator to measure pollution and to measure the organisms' ability to accumulate pollutants in their 
bodies. Therefore, it was necessary to find out the amount of lead in the whole organ of freshwater snails in Glagah subdistrict as an anticipation of its effect on ducks and human that consume the snails.

Brite et al., (2006) explained that maintaining the quality and the safety of food products can be done by reducing the amount of $\mathrm{Pb}$ in the snails. The amount of $\mathrm{Pb}$ can be reduced by conducting flushing procedure or by soaking the snails and flowing them with clean water before they are used as food for poultry and for human $(D K P, 2008)$. In line with this view, Chan et al. (1999) said that flushing off the heavy metals in snails can be done by moving them out from the contaminated habitat to a cleaner habitat. This research provides information on the appropriateness of freshwater snails to use as food for poultry and for human consumption. This research attempted at reducing the amount of $\mathrm{Pb}$ in freshwater snails (Filopaludina javanika v.d busch 1844) through flushing procedures.

\section{METHODS OF RESEARCH}

Freshwater snails around the size of $25-27 \mathrm{~mm}$ which were usually used as duck welt (Filopaludina javanika v.d busch 1844) were collected from ponds and rivers which were exposed to heavy metals including $\mathrm{Pb}$. The observation and the flushing procedures were conducted in the laboratory around the field. This reseach employed an experiment method using a complete randomized design with 4 treatments and 3 repetitions, including identification on the quality of the water $(\mathrm{pH}$, temperature, $\mathrm{DO})$ and the amount of $\mathrm{Pb}$ in the "whole organ" of the snails. The flushing procedure used clean freshwater that did not contain any $\mathrm{Pb}$ which was then filled into 12 containers. The flusing procedures used in this study were modified from the procedures performed by Nuriyani in 2016. Nuriyani (2016) showed that the soaking procedure did not give any significant effect without the changing of water.

The sample of freshwater snails used in the flushing procedure contained $\mathrm{Pb}$ amount beyond the safety limit set by BSN $(1.5 \mathrm{mg} / \mathrm{kg})$, DKP $(1.5 \mathrm{mg} / \mathrm{kg})$ Regulation of Food Specification NO 466/2001/EC (0.1 ppm) and Depkes (2 mg/kg). Each container was filled with water up to $20 \mathrm{~cm}$ for 4 different flushing periods of $6,12,18$ and 24 hours in 3 repetitions. The flushing speed at $0.43 \mathrm{~m} / \mathrm{second}$ was used regarding to the suggestions from previous studies by measuring the average water speed in the habitat. This speed was also determined from the previous study conducted by Ahmad (2012) in which the flushing of water at $0.43 \mathrm{~m} /$ second in 3 weeks has successfully reduced the amount of $\mathrm{Pb}$ in the shell of the snails from $1.19 \mathrm{ppm}$ to $0.45 \mathrm{ppm}(62.18 \%)$.

\section{RESULTS AND DISCUSSION}

The result of the first stage preliminary study done to the flesh of freshwater snail in Waung river showed the highest contamination of lead $(\mathrm{Pb})$ of $4.48 \mathrm{mg} / \mathrm{kg}$, whilst the least amount of lead $(\mathrm{Pb})$ was found in Bengawan Blawi river at $0.5 \mathrm{mg} / \mathrm{kg}$.

The sample collection in the stage 2 preliminary study was done in 4 locations which were the station 1 (Gayam Pond 1) located in the coordinate point $7^{\circ} 03^{\prime} 27.93^{\prime \prime} \mathrm{S}$ and $112^{\circ}$ $27^{\prime} 56.01^{\prime \prime} \mathrm{E}$, Station 2 (Gayam River) at $7^{\circ} 03^{\prime} 33.81^{\prime \prime} \mathrm{S}$ and $112^{0} 27^{\prime} 51.26^{\prime \prime} \mathrm{E}$, Station 3 (Gayam Pond 2) at $7^{0} 03^{\prime} 35.34 " \mathrm{~S}$ and $112^{\circ} 27^{\prime}$ 52.16" E, and Station 4 (Anak Kali Waung River) at $7^{0} 03^{\prime} 35.34^{\prime \prime} \mathrm{S}$ and $112^{\circ} 27^{\prime} 52.16^{\prime \prime} \mathrm{E}$.

The concentration of lead $(\mathrm{Pb})$ in the "whole organ" of the freshwater snails showed the highest value in Station 1 at 3.432 ppm, followed by Station 3 at 2.924 ppm, Station 2 at $2.402 \mathrm{ppm}$ and the lowest one was found in Station 4 at $0.07 \mathrm{ppm}$ (Figure 2). Regarding to the decision letters issued by the Ministry of Marine and Fisheries No: Kep 17/Men/2004 and National Standardization Institution (2009), the maximum limit of lead content is $1.5 \mathrm{ppm}$. Thus, the freshwater snails collected from station 1, 2, and 3 had reached over the safety limit, and only the ones found in station 4 were under the limit.

In the second preliminary study, the amount of lead $(\mathrm{Pb})$ in station 4 decreased from $4.48 \mathrm{ppm}$ to $0.07 \mathrm{ppm}$. The decrease was resulted by the increase on the water speed in 
Waung river from $0.5 \mathrm{~m} / \mathrm{second}$ to $1 \mathrm{~m} / \mathrm{second}$ in February until July 2017 . The faster water speed has flushed the amount of $\mathrm{Pb}$ within the flesh of the snails. Besides, mud litters thrown into the river from rice fields were low since it was not yet the harvest time. In the harvest time, farmers throw away the litters from their field into the river, causing high mud sedimentation in the river which forces freshwater snails to accumulate more $\mathrm{Pb}$ in their bodies. According to Purbalisa and Mulyadi (2013) the contamination of lead $(\mathrm{Pb})$ in the rice fields is assumed to come from the phosphate element as the impurities in the fertilizer. Phosphate fertilizer contains $\mathrm{P}_{2} \mathrm{O}_{5}$ as the primary element and it contains some secondary nutrients such as $\mathrm{Ca}, \mathrm{Mg}$ and other micro elements including $\mathrm{Fe}, \mathrm{Mn}, \mathrm{Cu}, \mathrm{Zn}$ and some heavy metals at various amount such as $\mathrm{Cd}(0.1-170 \mathrm{ppm}) \mathrm{Cr}(66-245 \mathrm{ppm}), \mathrm{Pb}(40-2000$ ppm), (Setyorini,2003).

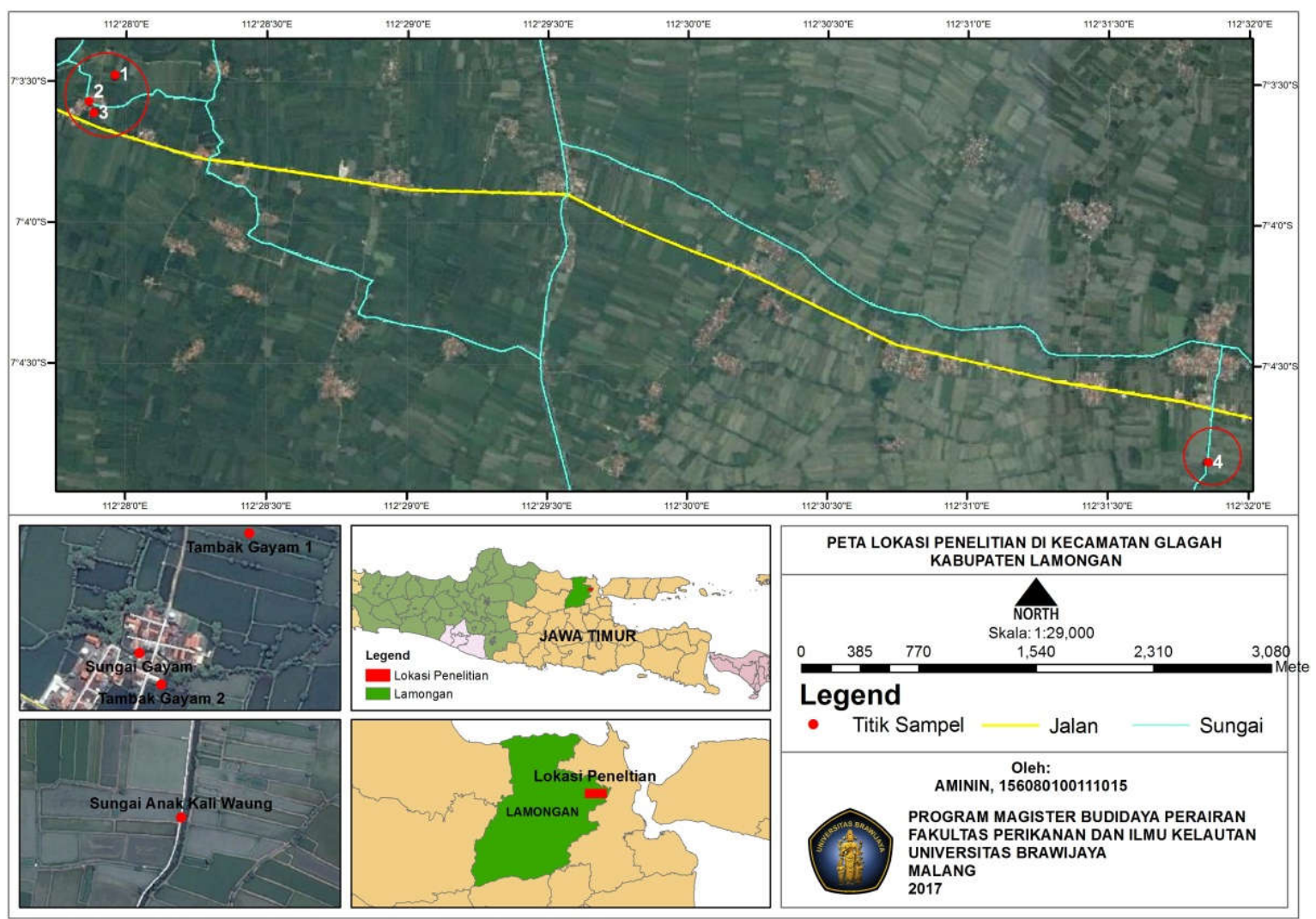

Figure 1 - The location of sample collection in the second stage preliminary study in Glagah subdistrict, Lamongan (Source: Google 2017 shapefile (SHP) Indonesian Geographical Images)

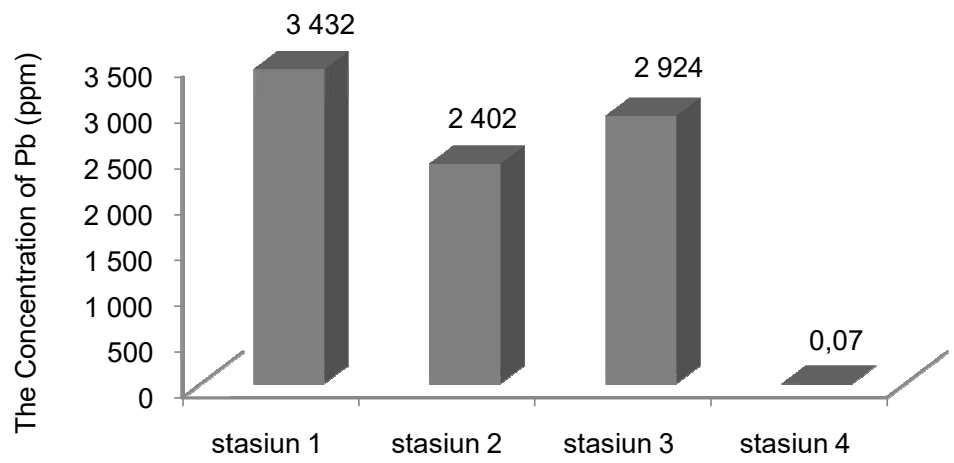

Figure 2 - Average lead $(\mathrm{Pb})$ concentration in rivers and ponds in Glagah Subdistrict, Lamongan (Notes: Stasiun 1: Gayam Pond 1; Stasiun 2: Gayam River; Stasiun 3: Gayam Pond 2; Stasiun 4: Anak Kali Waung River) 
Results of Flushing Procedure. Based on the result of this research, it can be concluded that the longer the flushing time, the higher the amount of ions flushed away from the flesh of the snails, which results to lower concentration of $\mathrm{Pb}$ in the snails. 6-hour flushing process has decreased the concentration of $\mathrm{Pb}$ as much as $7.2 \%$. The 12-hour flushing process has decreased $19.6 \%$ of the $\mathrm{Pb}$, leaving only $1.12 \mathrm{ppm}$. The 18-hour flushing process has decreased $38.1 \%$ of the $\mathrm{Pb}$ concentration, remaining only $1.64 \mathrm{ppm}$. The highest decrease of $\mathrm{Pb}$ was obtained from the 24-hour flushing process which has successfully decreased $53.2 \%$ of $\mathrm{Pb}$ concentration from $2.65 \mathrm{ppm}$ to $1.24 \mathrm{ppm}$. Regarding to the maximum limit of $\mathrm{Pb}$ concentration determined by the BPOM (2009) at $1.5 \mathrm{ppm}$, the concentration of $\mathrm{Pb}$ in freshwater snails after the flushing process is under the limit and is safe for human consumption.

Suprijanto et al. (1997) stated that depuration procedure decreases $\mathrm{Pb}$ concentration within the organisms' bodies since there is no addition of heavy metals from outside. The decreased concentration of $\mathrm{Pb} \mathrm{s}$ resulted form the release of metallic ions from the protein structure in the snails which are leached from their flesh as the balancer of $\mathrm{Pb}$ concentration in the flesh. Naturally, metallic ion exchange happens easily, especially to ions which are bounded to metalloprotein for metalloprotein chains are not stable (Wahyuni dan Widiyanti, 2004).

The result of Anova test has resulted an average concentration of $\mathrm{Pb}$ after the flushing procedure with a significant effect $(p<0.05)$. Hence, flushing procedure can be regarded highly effective in decreasing the concentration of $\mathrm{Pb}$ in freshwater snails. It happened due to the changing of water all the time which washed away the heavy metals in the snails' body. This insight goes in line with Riyadi (2016) who stated that clams are able to release heavy metals from their bodies which are later flushed away by ever flowing water circulation. Zhu et al., (1999) mentioned that the effort to clean clams and snails is often done in land with stable supply of flow-through water.

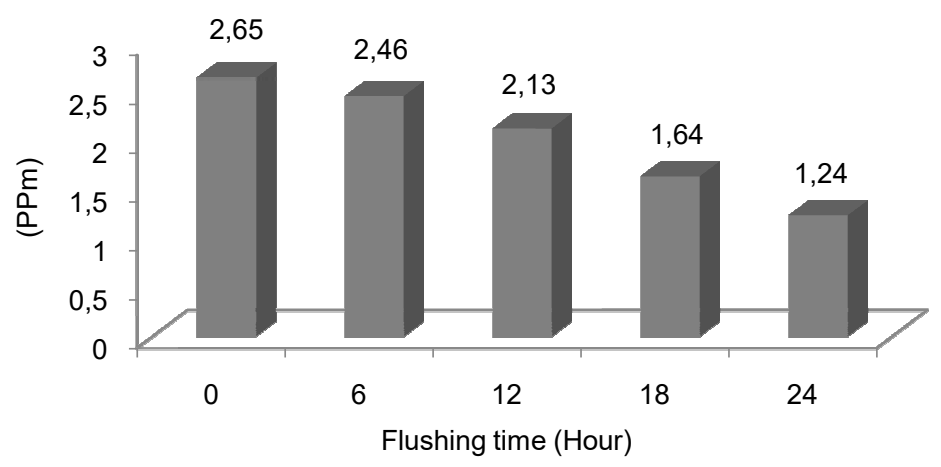

Figure 3 - The Result of AAS Test to the Whole Organ of Freshwater Snails after the Flushing Procedure

Water Quality. Physical and chemical parameters of the water were measured before and during the treatment. Water quality shows the relative condition of the water related to the necessities of creatures living in water. Moreover, the water quality also becomes the standard measurement to determine the quality of water ecosystem. Measurement was conducted on site in for each treatment including water temperature, $\mathrm{pH}$ and the dissolved oxygen (DO). The average score of the water quality measurement in each flushing process is presented in Table 1.

The average temperature during the flushing treatment was around $26.9-30.5{ }^{\circ} \mathrm{C}$. The average temperature shows that the water in the containers was favorable for the freshwater snails to live. Sumarni (1989) stated that most Mollusca, especially snails are able to live within the temperature of around $22-33{ }^{\circ} \mathrm{C}$. Meanwhile, Junting (1956) mentioned that Bellamnya javanika family Viviparidae are able to tolerate temperature up to $35^{\circ} \mathrm{C}$. generally, the $\mathrm{pH}$ found in each treatment was around 7.3-7.5. Hynes (1987) explained that usualy 
gastropods living in fresh water are able to live in $\mathrm{pH}$ level around $5.0-9.0$. Seen in Table 1, the $\mathrm{pH}$ of the water used in the research had been suitable with the ideal habitat of the freshwater snails. In line with Connel and Miller (1995); Novotny and Olem (1994), the increase of $\mathrm{pH}$ in the water is usually followed by the decrease of the solubility of the heavy metals, which makes the heavy metals to settle.

Table 1 - Average score of water quality during the flushing process

\begin{tabular}{cccc}
\hline \multirow{2}{*}{ Treatment (Hour) } & \multicolumn{3}{c}{ Parameters } \\
\cline { 2 - 4 } & Temperature $\left({ }^{0} \mathrm{C}\right)$ & $\mathrm{pH}$ & $\mathrm{DO}(\mathrm{ppm})$ \\
\hline 0 Hour & 29.9 & 7.3 & 3 \\
6 Hours & 27.1 & 7.3 & 2.8 \\
12 Hours & 26.9 & 7.4 & 3.3 \\
18 Hours & 30.2 & 7.4 & 3.4 \\
24 Hours & 30.5 & 7.5 & 4.0 \\
\hline
\end{tabular}

The result of the analysis on DO, the DO in each treatment tended to fluctuate. In the control treatment, the concentration of DO was found at $3 \mathrm{ppm}$, yet it decreased to $2.8 \mathrm{ppm}$ after being given 6 -hour flushing process. The decrease might be caused by the metabolism process of the freshwater snails (Filopaludina javanika v.d busch 1844) which requires high amount of oxygen. Rosita (2005) found in her research that performing depuration procedure decreases the DO of water. However, the increase in the concentration of DO in the water of immersion after the flushing process was rather caused by the aeration that works with the accordance of the gravity. In this context, the flowing water intensified the interaction between the air and the water, which gradually increased the concentration of the dissolved oxygen in the water (Wheaton, 1977).

\section{CONCLUSION AND SUGGESTIONS}

24-hour flushing procedure has been able to decrease the highest amount of $\mathrm{Pb}$ as much as $53.2 \%$ from $2.65 \mathrm{ppm}$ to $1.24 \mathrm{ppm}$. Thus, ater the treatment, the freshwater snails are safe for poultry feed and for human consumption. The flushing treatment conducted in this research has resulted to freshwater snails which are safe to consume based on the maximum limit of heavy metal contamination at $1.5 \mathrm{ppm}$ set by BPOM (2009), Fisheries (DKP) No: Kep 17/Men/2004, SK Ditjen POM No. 03725/B/SK/VII/1989.

Further research should be conducted to investigate the accumulation of $\mathrm{Pb}$ in ducks that consume freshwater snails that are contaminated with $\mathrm{Pb}$ within certain period of time.

\section{ACKNOWLEDGEMENT}

The deepest gratitude is expressed to BPP-DN Dirjen Dikti that has provided scholarship for the researchers' graduate studies.

\section{REFERENCES}

1. Ahmad, A. 2012. Pengaruh Perbedaan Kecepatan Aliran Air Terhadap Perubahan Kadar Logam Berat Timbal (Pb) Pada Cangkang Kijing Taiwan (Anodonta Woodiana). Skripsi. Fakultas Perikanan dan Ilmu Kelautan Universitas Brawijaya. Malang.

2. Anonim. 2007.Manfaat Keong Sawah di Lamongan http://Yulian.Firdaus.or.id/2007/02/08/tutut/. (22 Agustus 2017)

3. [BSN] Badan Standardisasi Nasional. 2009. Batas Maksimum Cemaran Logam Berat dalam Pangan. Badan Standardisasi Nasional. Jakarta.

4. Badan Pusat Statistik dan Pemerintah Kabupaten Lamongan. 2007. Lamongan Dalam Angka. Lamongan.

5. Brite, M., J, Dewi., dan Kurniastuty. 2006. Rekayasa Pengujian Depurasi Kekerangan dalam Upaya Meningkatkan Keamanan Bagi Konsumen. Jurnal Departemen Kelautan dan Perikanan. Jakarta. 
6. [DKP] Departemen Kelautan dan Perikanan. 2008. Budidaya kerang hijau (Perna viridis). http://www.indonesia.go.id/id/index.php.htm [15 Feb 2009].

7. Connel, D.W dan G,J. Miller. 1995. Kimia dan ekotoksikologi pencemaran. UI Press, Jakarta. $520 \mathrm{hlm}$.

8. Chan KW, Cheung RYH, Leung SF, Wong MH. 1999. Depuration of metal from soft tissue of oyster (Crassostrea gigas) transplanted from a contaminated site to clean sites. Environmental Pollution 105:299-310.

9. Hutagalung, H.P. 1991. Pencemaran Laut oleh Logam Berat dalam Beberapa Perairan Indonesi. Puslitbang Oseanologi LIPI, Jakarta. p. 1-20.

10. Purbalisa, W. Dan Mulyadi. 2013. Pb Dan Cu Pada Badan Air Dan Tanah Sawah SubDas Solo Hilir Kabupaten Lamongan. Jurnal. Balai Penelitian Lingkungan Pertanian. Jawa Tengah.

11. Hynes, H.B.N. (1978). The biology of polluted waters. Liverpool University press.London.

12. Jutting, W.S.S. (1956). Systematic Studies on The Non Marine Mollusca of the Indo Australian Archipelago. V. Critical Revision on The javanese Fresh Water Gastropods. Treubia.

13. Novotny, V.and Olem, H. 1994. Water Quality, Prevention, Identification and Managementof Diffuse Pollution. New York: Van Nostrans Reinhold

14. Riyadi P. H., Anggo A.D., dan Romadhon 2016. Efektifitas Depurasi Untuk Menurunkan Kandungan Logam Berat Pb Dan Cd Dalam Daging Kerang Darah (Anadara granossa). Prosiding Seminar Nasional Tahunan Ke-V Hasil-Hasil Penelitian Perikanan dan Kelautan. Universitas Diponegoro Semarang.

15. Rosita N. 2005. Efektivitas Kitosan dalam Menurunkan Kandungan Timbal (Pb) pada Kerang Hijau (Mytilus viridis) dengan Sistem Resirkulasi Sederhana [Skripsi]. Bogor: Program Studi Teknologi Hasil Perairan, Fakultas Perikanan dan IImu Kelautan, Institut Pertanian Bogor.

16. Sari, W.P., Bahtiar dan Emiyarti. 2016 Studi Preferensi Habitat Siput Tutut (Bellamya javanika) di Desa Amonggedo Kabupaten Konawe. Jurnal.. Fakultas Perikananan dan Ilmu Kelautan Universitas Halu Oleo. Kendari.

17. Setyorini, D., Soeparto, dan Sulaeman. 2003. Kadar Logam Berat Dalam Pupuk. Hal 219-229 dalam Risalah seminar peningkatan kualitas lingkungan dan produk pertanian. Kudus, 4 Nopember 2002. Puslittanak, Badan Litbang, Deptan.

18. Siregar, N. M. 2013. Analisis Kandungan Logam Berat Pb Dan Cd Pada Keong Tutut (Bellamya Javanica V.D Bush 1844) Di Waduk Saguling, Jawa Barat. Skripsi. Fakultas Perikanan Dan IImu Kelautan Institut Pertanian Bogor. Bogor.

19. Sumarni, 1989. Golden Shell Keong Mas Baru Penghuni Aquarium. Trubus No. 240 Th XX November. Yayasan Tani Membangun. Jakarta. Hal 217.

20. Sugianto,D,N. 1997. Tingkat Bioakumulasi Logam Berat Timbal (Pb) pada Jaringan Lunak kerang Bulu (Anadora Inflata reeve). Jurusan IImu Kelautan. Universitas Diponegoro, Semarang. 69 p.

21. Suprijanto, J., I. Widowati., P.W. Dyah., Widianingsih dan I. Hermawan. 1997. Bioakumulasi Logam Berat Timah Hitam (Pb) pada Jaringan Lunak Kerang (Anadara sp): Analisa Kualitatif dan Kuantitatif. Fakultas Perikanan dan IImu Kelautan. Universitas Diponegoro. Semarang. Laporan Hasil Penelitian (Tidak Dipublikasikan). 49 p.

22. Wahyuni, M. dan Widiyanti, S. 2004. Reduksi kadar merkuri pada kerang hij au (Mytilus viridis) di Teluk Jakarta melalui metode asam serta pemanfaatannya dalam metode kerupuk. Prosiding Seminar Nasional dan Temu Usaha. Universitas Sahid, Jakarta. p. 206-220.

23. Wheaton, F.W. 1977. Aquacultural Engineering , second printing. Robert E. Krieger Publishing Company. Malabar, Florida. 